\title{
Incidence of anti-intermediate filament antibody in serum samples of students with suspected glandular
} fever

\author{
PK KATAAHA, EJ HOLBOROW, JMB EDWARDS* \\ From the Bone and Joint Research Unit, The London Hospital Medical College, London E1, and the *Virus \\ Reference Laboratory, Central Public Health Laboratories, Colindale
}

SUMMARY Serum samples from 40 students with suspected infectious mononucleosis were tested for the presence of antibodies to intermediate filaments (AIFA) of the cytoskeleton. Twenty had antibodies to the Epstein-Barr virus capsid antigen before their illness, and during it their sera remained negative by the Paul-Bunnell test. The other 20 patients did not have antibodies to the Epstein-Barr virus capsid antigen before their illness and seroconverted during the illness. These patients (true infectious mononucleosis group) developed positive Paul-Bunnell tests. Sera from normal subjects (blood donors) were also tested for AIFA.

AIFA was present in titres $>1 / 10$ in $80 \%$ of the infectious mononucleosis group (mean titre $1 / 40-1 / 80$ ), $10 \%$ of the Paul-Bunnell negative glandular fever group, and $8.5 \%$ of the normal blood donors.

Anti-intermediate filament antibodies (AIFA) have been found in a variety of conditions, including rheumatoid arthritis, ${ }^{1}$ some parasitic diseases, ${ }^{2}$ and some acute viral conditions. ${ }^{34}$ A causal relation has been suggested between the latter and AIFA production ${ }^{4}$ because of falling titres of AIFA in paired acute and convalescent sera.

Although an association of AIFA with infectious mononucleosis has been reported, ${ }^{5}$ it is not clear whether this autoantibody is also present in clinically suspected "glandular fever" due to causes other than Epstein-Barr virus infection. We have investigated the incidence of AIFA in the sera of patients whose glandular fever was attributable to acute EBV infection and in those whose disease was due to other causes and in a group of blood donors.

\section{Material and methods}

\section{SERUM SAMPLES}

Serum samples from 40 patients participating in a joint investigation by university health physicians and Public Health Laboratory Service laboratories ${ }^{6}$ were available for testing. They were kindly made available to us by Dr TM Pollock and had been kept at $-20^{\circ} \mathrm{C}$ since their collection $(1970-4)$. The sam-

Accepted for publication 4 December 1984 ples were from students admitted to the University Health Centre with suspected glandular fever. Twenty samples came from students whose sera contained antibodies to the Epstein-Barr viral capsid antigen (VCA) before their illness, during or after which they had consistently had negative PaulBunnell tests. These 20 patients were negative for rubella seroconversion at the time of the illness. One patient showed a rise in anti-streptolysin $O$ titre from $1 / 250$ to $1 / 690$ and one showed a rise in complement fixation titre to herpes simplex from 0 to 1/320. Another three showed no significant changes in anti-streptolysin- $\mathrm{O}$ or anti-herpes simplex titres. No information was available for the remaining 15 patients regarding results of screening for antiviral antibodies. The other 20 sera came from students who were negative for anti-VCA IgG antibody before their illness. In these patients the PaulBunnell test became positive during their illness and EBV VCA IgM antibody was found. These findings were reported by Blake et al. ${ }^{7}$ A further 93 sera from healthy adult blood donors were also included in the present study.

ANTI-INTERMEDIATE FILAMENT ANTIBODY AIFA was detected by reacting sera with HEp 2 cells and human skin fibroblasts as substrate; the indirect immunofluorescence technique was used as 
described previously. ${ }^{1}$ Cells were seeded on multispot slides and cultured in RPMI 1640 (Gibco) supplemented with $10 \%$ fetal calf serum and antibiotics at $37^{\circ} \mathrm{C}$ in a humidified $5 \% \mathrm{CO}_{2}$ incubator until growth was subconfluent. Twelve hours before harvest colchicine was added to the cultures in a final concentration of $0.5 \mu \mathrm{g} / \mathrm{ml}$.

Slides carrying colchicine treated subconfluent HEp2 monolayers were rinsed thoroughly in warm phosphate buffered saline (PBS) $\left(37^{\circ} \mathrm{C}\right)$ and fixed in methanol at $-20^{\circ} \mathrm{C}$ for $10 \mathrm{~min}$. Drops of patients' sera at a dilution of $1 / 10$ were applied to the cells and the slides were kept at $37^{\circ} \mathrm{C}$ for $45 \mathrm{~min}$, after which they were washed in PBS and stained with poly- or monospecific fluorescein isothiocyanate conjugated sheep antihuman immunoglobulin (Wellcome Research Laboratories). Sera showing positive staining of intermediate filaments were titrated by doubling dilution. Results were read without knowledge of the other serological findings or the clinical state of the serum donors.

Sera positive for AIFA of vimentin specificity stained cytoplasmic filamentous bundles collapsed around the nucleus in colchicine treated HEp2 and fibroblast cells, as described previously. ${ }^{8}$ Those positive for AIFA of prekeratin specificity stained uncollapsed filaments that extended to the cell periphery in HEp2 cells only. Some sera gave both patterns of staining.

\section{Results}

The results are shown in the Figure. At a 1/10 dilution, $18(90 \%)$ of the 20 Paul-Bunnell positive samples, $7(35 \%)$ of the 20 Paul-Bunnell negative samples, and $24(25 \%)$ of the 93 blood donors' samples gave positive AIFA staining. On titration $16(80 \%)$ of the 20 Paul-Bunnell positive samples were positive at dilutions greater than $1 / 10$ (mean titre $1 / 40$ $1 / 80$ ). Of the Paul-Bunnell negative samples only two exceeded a $1 / 10$ in titre $(1 / 20,1 / 40)$. Of the 24 positive blood donor samples seven had titres of $1 / 20$ and one of $1 / 40$. All positive sera had IgM antibody only, except one of the Paul-Bunnell positive patients' samples, which was also positive for

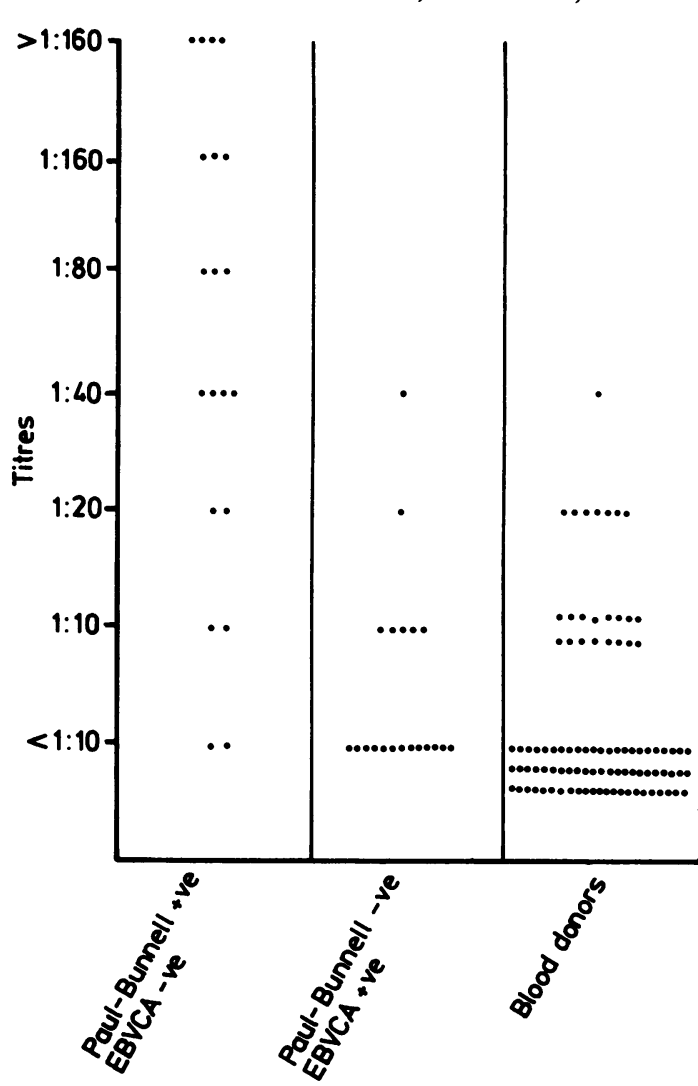

Titres of IgM anti-intermediate flament antibody in serum samples from patients with glandular fever and blood donors. The two sets of patients are divided by their Epstein-Barr viral capsid antigen (EBVCA) status before illness, indicating their state of susceptibility to Epstein-Barr virus infection. All the patients in the first column acquired EBVCA antibody during the illness.

IgG. The Table shows the staining patterns in the three groups of samples tested.

The possibility that prolonged storage at $-20^{\circ} \mathrm{C}$ of the patients' serum samples may have affected results seems reasonably excluded since a similarly

IgM staining patterns of anti-intermediate fllament antibody (AIFA) positive serum samples

\begin{tabular}{llcccc}
\hline Serum source & Total no & AIFA positive & Prekeratin pattern & Vimentin pattern & $\begin{array}{l}\text { Prekeratin and vimentin } \\
\text { patterns together }\end{array}$ \\
\hline Paul-Bunnell positive patients & 20 & 18 & 7 & 1 & $10^{*}$ \\
Paul-Bunnell negative patients & 20 & 7 & 4 & 0 & 3 \\
Blood donors & 93 & 24 & 4 & 1 & 19 \\
\hline
\end{tabular}

* One patient was positive for both IgG and IgM

Comparisons of the incidences of AIFA in the three groups by $\chi^{2}$ tests gave the following: Paul-Bunnell positive $v$ negative $p<0.001 \dagger$; Paul-Bunnell positive $v$ blood donors $\mathrm{p}<0.001$; Paul-Bunnell negative $v$ blood donors $\mathrm{p}>0.05 \ddagger$. $†$ significant; $\neq$ not significant. 
high incidence of AIFA in infectious mononucleosis has been reported previously ${ }^{3}{ }^{19}$; in the present study there was a significant difference in the behaviour of Paul-Bunnell positive and Paul-Bunnell negative glandular fever samples stored for the same lengthy period.

Of the samples from the five patients in the Paul-Bunnell negative group who had been screened for other viral conditions, one gave positive AIFA staining of prekeratin/vimentin type at a titre of $1 / 20$. This patient had a rising complement fixation titre to herpes simplex.

\section{Discussion}

In the initial larger study of suspected infectious mononucleosis in students, ${ }^{6}$ of which the patients reported here formed a part, almost all (44 of 45) of those who developed positive Paul-Bunnell tests at the onset of their illness also acquired anti-VCA antibodies, while no positive Paul-Bunnell test was shown in students whose illness did not result in acquisition of anti-EBV antibody. The availability of 40 carefully preserved serum samples from this study, together with information about the serological state of the serum donors before and during their illness, provided an opportunity to seek a possible relation between the presence of AIFA and proof of EBV infection as the cause of clinically suspected "glandular fever." AIFA is one of a variety of IgM autoantibodies which have been found in infectious mononucleosis, which include antinuclear antibodies, ${ }^{9}$ anti-immunoglobulin antibodies, ${ }^{9}$ anti-i antibodies, ${ }^{10}$ anti-smooth muscle antibodies, ${ }^{11}$ and anti-lymphocyte antibodies. ${ }^{12}$ In one report ${ }^{5}$ AIFA of IgG class showed no clear cut disease associations.

In our group of $\mathbf{4 0}$ patients with clinically suspected infectious mononucleosis we found clear evidence that AIFA of IgM class occurred in significantly higher incidence and titre in the 20 whose illness was serologically shown to be attributable to EBV infection. The 20 patients whose sera remained negative for heterophile antibody by Paul-Bunnell testing were also negative for rubella seroconversion. Evidence for the cause of their illness is fragmentary since results of serological tests for other microbial agents were available for only five: only two were positive, one for antistreptolysin- $O$ and one for antibody to herpes simplex.

We have previously reported ${ }^{13}$ that IgM AIFA is induced in lymphocyte cultures infected with EBV and that increased IgM levels in the supernatants of such cultures are accompanied by the appearance of another autoantibody, rheumatoid factor. ${ }^{14}$ It thus appears that both in vivo and in vitro the polyclonal activating effect of EBV on B lymphocytes results in autoantibody production. The results reported here suggest that EBV infection especially favours production of IgM antibody specific for intermediate filaments as shown by immunofluorescence. In view of recent reports ${ }^{15-18}$ concerning the cross reactivities of AIFA, however, further studies are needed to define more precisely the specificities of these antibodies found in patients' sera.

\section{References}

' Osung $\mathrm{O}$, Chandra M, Holborow EJ. Antibody to intermediate filaments of the cytoskeleton in rheumatoid arthritis. Ann Rheum Dis 1982;41:69-73.

${ }^{2}$ Mortazavi-Milani SM, Holborow EJ. Antibody to intermediate filaments of the cytoskeleton in the sera of patients with acute malaria. Clin Exp Immunol 1984;55:177-82.

${ }^{3}$ Linder E, Kurki P, Andersson LC. Autoantibody to "intermediate filaments" in infectious mononucleosis. Clin Immunol Immunopathol 1979;14:411-7.

4 Toh BH, Yildiz A, Sotelo J, et al. Viral infections and IgM autoantibodies to cytoplasmic intermediate filaments. Clin Exp Immunol 1979;37:78-82.

${ }^{5}$ Kurki P, Virtanen I, Stenman S, Linder E. Characterization of human smooth muscle autoantibodies reacting with cytoplasmic intermediate filaments. Clin Immunol Immunopathol 1978;11:379-87.

- A joint investigation by university health physicians and PHLS Laboratories. Br Med J 1971;iv:643-6.

' Blake JM, Edwards JMB, Fletcher W, McSwiggan DA, Pereira MS. Measurement of heterophile antibody and antibodies to EB viral capsid antigen IgG and IgM in suspected cases of infectious mononucleosis. J Clin Pathol 1976;29:841.

${ }^{8}$ Franke WW, Schmid E, Osborn M, Weber K. Different intermediate sized filaments distinguished by immunofluorescence microscopy. Proc Natl Acad Sci USA 1978;75:5034-8.

${ }^{9}$ Holborow EJ, Asherson GC, Johnson GD, Barnes RDS, Carmichael DC. Antinuclear factor and other antibodies in blood and liver diseases. Br Med J 1963;i:656.

${ }^{10}$ Wollheim FA, Williams RC. Studies on the macroglobulins of human serum. I. Polyclonal immunoglobulin class M (IgM). Increases in infectious mononucleosis. $N$ Engl $J$ Med 1966;274:61.

" Holborow EJ, Hemsted EH, Mead SU. Smooth muscle antibodies in infectious mononucleosis. Br Med J 1973;iii:323.

12 Sutton RNP, Edmond RTD, Thomas B, Doniach D. The occurrence of autoantibodies in infectious mononucleosis. Clin Exp Immunol 1974;17:427-36.

${ }^{13}$ Mortazavi-Milani SM, Stierle HE, Holborow EJ. In vitro induction of anti-intermediate filament antibody in lymphocyte cultures by Epstein Barr virus. Immunology Letters 1982;5:203-5.

14 Santana R, Stierle HE, March RE, Holborow EJ. Analysis of polyclonal rheumatoid factors by isoelectric focusing. $J$ Immunol Methods 1983;61:129-30.

${ }^{15}$ Dulbecco RM, Unger M, Bologna M, et al. Cross-reactivity between Thy-I and Component of intermediate filaments demonstrated using a monoclonal antibody. Nature 1981;292:772-4.

${ }^{16}$ Sonenberg N, Trachsel H. Probing the function of the eukaryotic 5 -cap structure using monoclonal antibodies to cap-binding proteins. Current Topics in Cellular Regulation 1982;21:83-4.

${ }^{17}$ Fujinami RS, Oldstone MBA, Wroblewska Z, Frankel M, Kop- 
rowski H. Molecular mimicry in virus infection: cross reaction of measles virus phosphoprotein or of herpes simplex virus protein with human intermediate filament. Proc Natl Acad Sci USA 1983;80:2346-50.

${ }^{18}$ Dales S, Fujinami RS, Oldstone MBA. Infection with vaccinia favours the selection of hybridomas synthesizing autoantibodies against intermediate filaments, one of them crossreacting with the virus haemagglutinin. J Immunol 1983;31:1546-53.

${ }^{19}$ Milani MM, Osung OA, Badakere SS, Chandra M, March RE, Holborow EJ. Antibodies to cytoskeletal intermediate filaments in rheumatoid arthritis, osteoarthritis and infectious mononucleosis. Proceedings of the 15th international congress of rheumatology, Paris, 1981. Abstract 0043.

Requests for reprints to: Professor EJ Holborow, Bone and Joint Research Unit, The London Hospital Medical $\triangle$ College, 25-29 Ash Field Street, London E1 2AD, England.

\section{The February 1985 issue}

\section{THE FEBRUARY 1985 ISSUE CONTAINS THE FOLLOWING PAPERS}

Biochemical enzyme analysis in acute leukaemia HG DREXLER, G GAEDICKE, J MINOWADA

Kinetics, distribution, and sites of destruction of indium-111 oxine labelled red cells in haemolytic anaemia AduP HEYNS, MG LŌTTER, HF KOTZÈ, P WESSELS, H PIETERS, PN BADENHORST

ICSH/ICTH recommendations for reporting prothrombin time in oral anticoagulant control INTERNATIONAL COMMITTEE FOR STANDARDIZATION IN HAEMATOLOGY AND INTERNATIONAL COMMITTEE ON THROMBOSIS AND HAEMOSTASIS

Erythrocyte deformability in peripheral occlusive arterial disease D BAREFORD, GS LUCAS, NM CALDWELL, PCW STONE, S BAAR, J STUART

Immunohistochemical localisation of tissue plasminogen activator and urokinase in the vessel wall Å LARSSON, B ÁSTEDT

Heart transplant pathology: the British experience ARIELA POMERANCE, PGI STOVIN

Giant cell myocarditis: evidence for the macrophage origin of the giant cells JM THEAKER, KC GATTER, A HERYET, DJ EVANS, J O'D McGEE

Immunohistological diagnosis of central nervous system tumours using a monoclonal antibody panel HB COAKHAM, JA GARSON, PATRICIA M ALLAN, EDNA I HARPER, BETTY BROWNELL, JT KEMSHEAD, E BIRGITTE LANE

Assessment of dysplasia in colorectal adenomas: an observer variation and morphometric study LJR BROWN, NC SMEETON, MF DIXON

Immunocytochemical reaction of $\mathrm{Ca} 1$ and HMFG2 monoclonal antibodies with cells from serous effusions S SINGER, MM BODDINGTON, EA HUDSON
Liver aspiration in the diagnosis of hepatocellular $\stackrel{G}{\rightarrow}$ carcinoma in the Gambia A AJDUKIEWICZ, A CROWDEN, ELIZABETH HUDSON, C PYNE

Serial study of $C$ reactive protein concentrations in cardiac allograft recipients GD HARKISS

Study of discrepancies in rubella haemagglutinin titrations and a reappraisal of diluents used in the rubella haemagglutination inhibition techni- of que HGS MURRAY, JUDITH STANTON, PS GARDNER Comparison of five different methods of rubella IgM antibody testing HEATHER CUBIE, ELIZABETH EDMOND

A study of workload units in five microbiology laboratories RY CARTWRIGHT, JOAN R DAVIES, C DULAKE, RJC HART, CA MORRIS, PJ WILKINSON

Microcomputer system for multistep specimen processing and reporting in a microbiology laboratory R ASHLEY, B DOWNING

Development and application of an enzyme linked immunosorbent assay for Clostridium perfringens type A enterotoxin BARBARA A BARTHOLOMEW, MF STRINGER, GN WATSON, RJ GILBERT

Leucocyte esterase determination as a secondary procedure for urine screening PMLEIGHTON, JA LITTLE

\section{Technical method}

Effect of antibiotic concentration in a selective medium on the isolation of Clostridium difficile from o faecal specimens PN LEVETT

Letters to the Editor

Book reviews

Notices 